\title{
Research on the Influence of ODM Mode on Consumer Decision
}

\author{
Ming Tian*, \\ School of Economics and Management, Beijing Jiaotong University, Beijing, China
}

\begin{abstract}
As an emerging new consumption model, the ODM e-commerce model accurately locates consumers and uses consumers' shopping needs as the marketing strategy of the e-commerce platform. This is a huge impact on traditional physical sales and existing e-commerce models. In order to explore the relationship between ODM model products and consumer decision-making, this article takes the NetEase selected represented by ODM e-commerce model as the research object. The results found that there is a significant positive correlation between the types of commodities and ODM model and consumer decision-making. Consumer participation has a positive regulatory effect on the relationship between ODM model and consumer decision-making. The research conclusions provide theoretical support for the ODM e-commerce model to increase user stickiness, increase consumer decision-making weight, and expand marketing models.
\end{abstract}

\section{Introduction}

In recent years, our country's e-commerce industry has developed vigorously, and various types of e-commerce websites have sprung up, greatly enriching consumers' shopping methods and satisfying the shopping needs of different consumers. With the continuous development and growth of the e-commerce industry, a series of new e-commerce sales models have been born. Consumers have also experienced various vertical e-commerce model changes from $\mathrm{C} 2 \mathrm{C}$ to $\mathrm{B} 2 \mathrm{C}$ to $\mathrm{ODM}$ new consumption. Online shopping gradually become the new normal in the retail industry, especially the ODM e-commerce model represented by NetEase selection. Once it emerged, it quickly became a new consumption model leading other types of e-commerce platforms and grew into the most influential vertical e-commerce brand at this stage.

\section{The background and significance of the ODM model}

With the continuous development of social economy, people's living standards are rapidly improving, and more and more people are entering the new middle class. Consumers have a higher pursuit of product style and quality, our country is in a new consumption era of consumption upgrades. NetEase CEO Ding Lei mentioned: our country's consumer groups are undergoing an evolution. In the past, everyone was pursuing how to buy, but now

* Corresponding author: 19125548@bjtu.edu.cn 
everyone is pursuing how to buy better and more tasteful. This phenomenon is called new consumption, and it focuses on the changes in consumers' consumption view and consumption behavior.

Simultaneously with the emergence of new consumer concepts, the e-commerce traffic dividend period has faded, and it has begun to enter a bottleneck period and a transition period when the growth rate is gradually slowing down, the structure is relatively solidified, and the competition is significantly intensified. For early consumers, online shopping is a new thing. Compared with offline shopping, the emergence of e-commerce enables consumers to choose a variety of products online without leaving home. The $\mathrm{C} 2 \mathrm{C}$ e-commerce model by TaoBao has come into being, covering all aspects of life, and satisfying consumers' willingness to shop conveniently and quickly. When consumers are used to the e-commerce shopping model, businesses will not hesitate to sell fakes in order to get higher profits. Ensuring that the purchase of genuine products on the e-commerce platform has become a topic that consumers really care about. In this context, the $\mathrm{B} 2 \mathrm{C}$ e-commerce model represented by JD.com is brand-oriented and caters to consumers' demand for authentic products.

The global market research company Euromonitor released a report on the top ten global consumer trends in 2020, pointing out that with the increase in purchasing power, consumers are pushing brands to accept their values, that is, consumers refuse mass production and ordinary products, and tend to simple and return to basic needs ${ }^{1}$. Consumers expect truly differentiated products and experiences ${ }^{2}$. At the same time, under the guidance of the supplyside reform policy, our country's manufacturing industry is also accelerating its transformation and upgrading ${ }^{3}$. Many domestic manufacturers have already had the production of higher-quality products and certain design capabilities. In this economic context, the ODM e-commerce model represented by NetEase selected is more in line with the psychological needs of modern consumers. This trend reflects the transformation of the power relationship between sellers and consumers. In the past, consumers had to rely on specific brands or information sources to buy the goods they needed. Now, companies must continue to innovate, lower prices, improve and beautify products can attract consumers.

\section{Brief description of the ODM model}

With the development of China's manufacturing industry, it has been possible to produce high-quality products with first-class equipment, production technology, management capabilities and technical personnel, and the foundry has become a skilled factory in China. The foundry is a manufacturer in the OEM model. Its full name is Original Equipment Manufacturer. However, with the rapid development of OEMs in India, Vietnam and other countries, low-cost labor changes in the international situation, China's manufacturing industry is facing the problem of reduced foreign trade orders, overcapacity, and the continuous development of the domestic economy ${ }^{4}$. People are no longer just the pursuit of low-cost products, but more of the high-quality products, so the foundry is facing an extremely urgent need for transformation ${ }^{5}$.

At present, there are two main channels for factory transformation. One is to create its own brand to realize the OBM production mode. Its full name is Original Brand Manufacturer, which means that the factory operates its own brand, or the manufacturer creates its own products, produces and sells products with independent brands. Since OEMs need to have a complete marketing network to support OBM, the effort and cost required are much higher than OEMs, and their own brands will conflict with their own OEM customers, few OEMs can transform to create its own brand.

The other is to realize the ODM production mode. The full name is Original Design Manufacturer, which means that after a manufacturer designs a certain product, it may be favored by other companies, require the latter's brand to be used for production, or slightly 
modify the design to produce. Among them, the manufacturer that undertakes the design and manufacturing business is called the ODM manufacturer, and the product it produces is the ODM product ${ }^{6}$. Different from traditional e-commerce, the ODM model goes beyond intermediate channel providers and directly connects to high-quality upstream manufacturers. It goes deep into the entire supply chain of product selection, production, sales, logistics, and after-sales. It follows the pricing rule of "cost price + value-added tax + postage", eliminating high brand premiums, advertising, and intermediary costs, and achieving the "de-branding" of high-quality products ${ }^{7}$. Coupled with the impact of the COVID-19 this year, many sales have moved from offline to online. It is also difficult for e-commerce companies to control the construction period and quality of foundry products. Therefore, under the special economic background, with the high-quality and low-price service concept, it can attract more consumers, have a large number of audiences, and better reflect its characteristics.

Once the ODM e-commerce model represented by NetEase selected has emerged, it has quickly become a new consumption model that leads other e-commerce platforms, such as Taobao Xinxuan and JD.made, which have had a huge impact on the traditional e-commerce operation model. The mass foundry mode of production is gradually replaced by small batches of customized production. Small and refined products are more in line with the consumption concept of the modern new middle class, and there is a larger consumer market.

The ODM e-commerce model focuses on differentiated marketing strategies. Under the background of new consumption upgrades, our country's manufacturing industry accelerates the pace of supply-side reform, the expansion of enterprises stimulates domestic demand, and reduces consumers' growing needs for a better life, as well as unbalanced and insufficient development. The contradiction between the two has major strategic influence and significance. Existing research on ODM models mostly studies the operation management and development strategies of ODM models from the upstream perspective, that is, the supply chain perspective, and rarely studies the ODM e-commerce models from the downstream perspective, that is, the consumer perspective. In order to have a deeper understanding of the influence mechanism of ODM e-commerce model on consumer decision-making, this article uses NetEase selected of e-commerce platform as the research object to explore the influence mechanism of ODM e-commerce model on consumer decision-making under the influence of new consumption concepts. Provide a modest force for the optimization and development of the ODM e-commerce model.

\section{NetEase selected overview}

As NetEase's original life-quality e-commerce platform, NetEase selected is the first ecommerce company to adopt the ODM model, focusing on home life and other products. Advocate the business philosophy of "good life, not so expensive", connect directly with famous manufacturers, eliminate brand premiums and intermediate links, and select highquality, high-quality products for consumers. NetEase selected positions its audience as the new middle class. Most consumers are between 20 and 35 years old. This part of consumers is characterized by limited income but pursuing high-quality life. The first choice for consumption is rational consumption that focus on product content and tend to products with high quality and low price that improve the quality of life ${ }^{8}$. In order to meet the needs of consumers, NetEase selected has always adhered to the standard of excellence in product selection, saving consumers time and cost of purchasing products.

The entire process from production to sales of the products on the NetEase selected platform is a standard ODM operation process. Therefore, this article uses the NetEase selected as the research object. In this platform, each product can be collected from the shelves, views, and collections. Inventory, sales volume, repurchase rate and other 
information, through the development of data sets, data analysis can be used to analyze the impact of ODM e-commerce model products on consumer shopping decisions.

\section{The influence of ODM mode on consumer decision-making}

\subsection{Data Collection}

Use a Java-based web search engine to collect data from the official website of NetEase selected, and use commodities as the unit of data collection. From the official website, you can see that NetEase selected includes eight categories, such as home life, clothing, shoes and bags, food and beverages, personal care, cleaning, maternal and child parenting, sports travel, digital home appliances, and strict selection of global. Different categories of goods have different effects on consumers' shopping decisions. So this article uses the commodity categories of NetEase selected as control variables to analyze. As of December 23, 2019, the NetEase selected homepage has 4,293 products. In order to improve the accuracy of data analysis, different attributes of products will be captured, such as product sales, product evaluation and other data. According to whether the product has the "NetEase self-operated brand" logo, the ordinary products and ODM model products of the NetEase selected platform are distinguished. Since the platform cannot capture the sales volume, according to the characteristics that the evaluation volume is basically consistent with the sales volume ${ }^{9}$. The evaluation volume is used as the data of the sales volume. The number of additional reviews based on the product is used as the analysis data of consumer participation. In addition, it also includes the category of the product. After collecting the data, the data is normalized to lay the foundation for subsequent empirical analysis. In order to avoid deviations from the analysis of the model due to the type of commodities, the commodity category is analyzed as a control variable.

\subsection{Define research variables}

In order to analyze the impact of the ODM model on consumer decision-making, this paper analyzes the collected data based on the SPSS software platform. The product category is used as the control variable, the ODM model product is used as the independent variable, and the product sales volume is the dependent variable. Consumer participation is used as a moderating variable. The specific measurement methods of the variables are shown in Table 1. 
Table 1. Variable measurement.

\begin{tabular}{|c|c|c|c|}
\hline Variable & & Description & Measurement \\
\hline $\begin{array}{l}\text { Independent } \\
\text { Variable }\end{array}$ & ODM & $\begin{array}{l}\text { Whether the product is self } \\
\text { owned brand of NetEase. }\end{array}$ & $\begin{array}{l}0: \text { Non self owned } \\
\text { brand of NetEase } \\
\text { 1: Self owned brand } \\
\text { of NetEase }\end{array}$ \\
\hline $\begin{array}{l}\text { Dependent } \\
\text { Variable }\end{array}$ & $\begin{array}{l}\text { Sales volume of } \\
\text { goods }\end{array}$ & $\begin{array}{l}\text { The quantity of productin } \\
\text { sold. }\end{array}$ & evaluation quantity \\
\hline $\begin{array}{l}\text { Moderator } \\
\text { Variable }\end{array}$ & $\begin{array}{l}\text { Consumer } \\
\text { continued } \\
\text { participation }\end{array}$ & $\begin{array}{l}\text { Whether the consumer has } \\
\text { any additional comments } \\
\text { after purchasing the } \\
\text { product. }\end{array}$ & $\begin{array}{l}0: \text { No additional } \\
\text { comments } \\
\text { 1: Having } \\
\text { additional } \\
\text { comments }\end{array}$ \\
\hline $\begin{array}{l}\text { Control } \\
\text { variable }\end{array}$ & $\begin{array}{l}\text { FMCG (Fast } \\
\text { Moving Consumer } \\
\text { Goods) }\end{array}$ & $\begin{array}{l}\text { Whether the product is } \\
\text { FMCG type }\end{array}$ & $\begin{array}{l}\text { 0: Not FMCG } \\
\text { 1: FMCG }\end{array}$ \\
\hline
\end{tabular}

ODM: This variable is Whether the product is self-owned brand of NetEase. Use "NetEase self-operated brand" as the distinguishing mark of this variable, and code the logo with "NetEase self-operated brand" in the crawled product data as "1", and code "0" without this logo.

Sales volume of goods: This variable is the quantitative data representation of the model. There is no merchandise sales volume displayed on this platform. According to the default evaluation and content evaluation in the evaluation volume, it can be basically assumed that the evaluation volume is consistent with the merchandise sales volume data.

Consumer continued participation: This variable is the expression of consumer participation in the product after receiving the product. Use the additional comment of the product as the variable. If there is an additional comment, the product is coded as "1", and if there is no additional comment, the code is " 0 ".

Control variable: The product category is used as control variables. Due to the relatively low threshold of ODM for apparel, footwear and bags, many businesses will form an ODM model to increase profits. In order to reduce the impact, it will be used as the control variables.

\subsection{Descriptive statistical analysis}

From the perspective of the overall commodity attributes of NetEase selected, ODM model products account for the vast majority $(78.9 \%)$, and there are still some non-ODM model products $(21.1 \%)$. Among them, home life, food and beverages, clothing, shoes and hats, and selected Global's products on the NetEase selected platform accounted for $16.1 \%, 13.4 \%$, $19.1 \%$ and $26.1 \%$ of the total number of products respectively. Since NetEase selected adjusts its operation and sales plans according to consumers' needs and feedback, the quantity ratio of product categories and ODM products in each product category also confirm the positioning of NetEase selected for consumers. New middle-class consumers who have a certain spending power and tend to have a higher quality of life. They are generally between 25 and 35 years old, and they pay more attention to quality life and healthy life.

In the survey of consumer participation, it was found that among the products on the NetEase selected, products with review accounted for $74.9 \%$ of the total number of products, of which ODM products accounted for $82.7 \%$ of the total number of products with review. Commodities accounted for $25.1 \%$ of the total number of commodities. On the whole, the 
high level of consumer participation on the NetEase selected indicates that users are more sticky and the shopping platform is more active. From the product categories, except for the strict selection of the global product category, the number of products reviewed for the other seven categories accounted for more than $80 \%$ of the total number of products in each category. ODM products also accounted for the vast majority, indicating that NetEase consumers on the selected platform are willing to share their willingness to use with other consumers, which also helps the platform increase the weight of consumers' decision-making when choosing products, which has a certain impact on consumers' shopping choices.

\subsection{Correlation analysis}

Use SPSS software to analyze the correlation between ODM model products and consumer decision-making, use product categories as control variables, ODM products as independent variables, product sales as dependent variables, and consumer participation as a moderating variable to construct a model. The method of stepwise hierarchical regression is adopted. Model 1 is the correlation analysis between control variables and consumer decision-making; Model 2 adds independent variables to analyze the correlation between ODM model goods and consumer decision-making; Model 3 adds moderating variables to analyze consumer participation in ODM model The impact of the relationship between goods and consumer decisions. The results of stepwise hierarchical regression analysis are shown in Table 2.

Table 2. Hierarchical regression results.

\begin{tabular}{|l|l|l|c|}
\hline Variable & Model 1 & Model 2 & Model 3 \\
\hline Dependent variable: Sales volume of goods & & & \\
\hline Control variable & $0.250^{* * *}$ & $0.253^{* * *}$ & $0.229^{* * *}$ \\
\hline FMCG & & & \\
\hline Independent variable & & $0.159^{* * *}$ & $0.145^{* * *}$ \\
\hline ODM & & & \\
\hline Moderator effect & & & $0.181^{* * *}$ \\
\hline $\begin{array}{l}\text { Consumer continued participation * ODM } \\
\text { products }\end{array}$ & & & -0.032 \\
\hline Constant & $1.406 \mathrm{E}-15$ & $1.298 \mathrm{E}-15$ & 0.130 \\
\hline R-square & 0.075 & 0.100 & \\
\hline Observations & 3474 & & \\
\hline
\end{tabular}

Note: ${ }^{*} \mathrm{p}<.10 ; * * \mathrm{p}<.05 ; * * * \mathrm{p}<.01$. All tests are tailed.

The correlation analysis results show that in Model 1 , the product category and consumer decision-making show a positive correlation $\left(\beta=0.250^{* * *}\right)$; in Model 2 , the independent variables are added to the model, and the correlation analysis results show that ODM There is a significant positive correlation between model products and consumer decision-making $\left(\beta=0.159^{* * *}\right)$. As the control variable of product category, its correlation with consumer decision-making has no significant change; in Model 3, the consumer participation As a moderating variable, the analysis results show that consumer participation has a positive regulatory effect on the relationship between ODM model products and consumer decisionmaking $\left(\beta=0.181^{* * *}\right)$. The closer the relationship between ODM model products and consumer decision-making. 


\section{Conclusion}

This paper takes the NetEase selected platform represented by the ODM e-commerce model as the research object, and explores the relationship between ODM model products and consumer decision-making. The research found that there is a significant positive correlation between ODM model products and consumer decision-making. There is also a significant positive correlation between consumer decisions, and consumer participation has a positive regulatory effect on the relationship between ODM model products and consumer decisions. The research conclusions provide theoretical support for the ODM e-commerce model to increase user stickiness, increase consumer decision-making weight, and expand marketing models.

\section{References}

1. Ten global consumption trends in 2020, [online] Available: http://xue.ecduo.cn/article78899.html

2. Q. Wang, The Effect and Mechanism of "Internet+" Promoting my country's Consumption Upgrade, Series of Finance and Economics: Journal of Zhejiang University of Finance and Economics, 12, (2016).

3. M. Le, Wiley, Creating Strategic Leverage: Matching Company Strengths with Market Opportunities, Wiley, 9, 4, (1992).

4. Q. Luo, The Dilemma and Countermeasures of China's Manufacturing Industry Development, 2nd International Conference on Contemporary Education and Humanities and Social Sciences, (2017).

5. Davies, Antony, and T. W. Cline, A consumer behavior approach to modeling monopolistic competition, Innovar Revista De Ciencias Administrativas Y Sociales 26(6), 797-826, (2006).

6. R. Chen, Analysis of NetEase's strict selection model based on the new consumption era, Market Modernization, 15, (2018).

7. T. Q. Hao, Z. Z. Ma, Z. H. Yang, et. al ODM model quality e-commerce under consumption upgrades-taking NetEase's strict selection as an example, Economic and Trade Practice, 230, 12, (2018).

8. Y. Ling, Computer Science in Industrial Application, (2015).

9. N Hu, L Liu, J. J Zhang, Do online reviews affect product sales? The role of reviewer characteristics and temporal effects, Information Technology \& Management, 9, 2008. 